\title{
Medicinal Plants: A Prospect in Developing Male Fertility Enhancing Agent
}

\author{
Muhammad Ja'far Luthfi ${ }^{1 *}$, Mahanem Mat Noor ${ }^{2}$ and Jalifah Latip ${ }^{3}$ \\ ${ }^{1}$ Biology Department, Faculty of Science and Technology, UIN Sunan Kalijaga \\ J1. Marsda Adisucipto No 1 Yogyakarta 55281, Indonesia. Tel. +62-274-540971, Fax. +62-274-519739 \\ ${ }^{2}$ The Study Center of BioScience and Biotechnology, ${ }^{3}$ The Study Center of Chemical Science and Food Technology, \\ Faculty of Science and Technology, UKM 43600 Bangi, Selangor, Malaysia \\ Author correspondency*: \\ jafarluthfi@yahoo.com
}

\begin{abstract}
Medicinal plants have been a revolutionary breakthrough in the treatment of male sexual dysfunction. Traditional medicine based on a holistic philosophy is quite different with the practice of "western" medicine. Phytochemical substances focus their mechanisms of healing to the root of cause, i.e. the inability of controlling the proper function of the whole body system. Hence, medicinal plants manage sexual dysfunction and male fertility in the frame of sexual dysfunction as a whole entity. Some previous researches prove that the use of medicinal plants have a good impact in the treatment of a variety of male sexual problems. This paper will discuss several important aspects of aphrodisiac plants and preliminary study regarding them in Indonesia. Difficulties inherent to activity guided isolation and the specific requirements of bioassays are also discussed.
\end{abstract}

Keywords: medicinal plants, male sexual problem, traditional medicine

\section{Introduction}

Male sexual dysfunction is a very serious problem. (MacKay, 2004; Clourate, 2005). Approximately 10\% men are infetile, and 50\% infertile couple are from male factors. (Pei et al., 2005). The medical treatment for male sexual problem has not succeeded yet although many efforts have been done (Hamadeh, 2001; Kohn, 2001). The existed modern methods, like assisted reproductive technology (ART), need high cost while the result is not consistent (Orgebin-Crist, 1998), even the methods have side effects (Levie'vre et al., 2007).

People have used plants as medicine since the beginning of human civilization, even probably have been used before they evolved to be man, as shown in the practice of using medicinal plants by non-human primates (Newton, 1991). One of the use of medicinal plants is to overcome sexual dysfunction.

Indonesia is one of the mega-biodiversity countries. There are many potential plant as aphrodisiac agent. However there is little scientific evidence supporting the effectiveness of using aphrodisiac plants. Besides that, there is still less studies of the action mechanism and its active components. The profound research of the effect of plants towards male reproductive system will support the use and the effectiveness of the medicinal plants.

The paper will discuss about several important issues of medicinal plants to cure male sexual problem covering the characteristics, the research, and the development of the medicinal plants. Those plants include aphrodisiac plants and those which function to improve the fertility. It also discusses about the research of several plants used by local people.

\section{The research of drug from plant sources}

Plants is a main source of new drug discovery (Balandrin et al., 1985), approximately $40 \%$ modern drugs are from botanical substances (LaFrance Jr. et al., 2000). However, recently many pharmaceutical industries have reduced plant drugs studies. Compared with synthetic drugs, plant drugs are not suitable for High-Throughput Screening. The study and evaluation of plant drug are very complicated, time-consuming, and more expensive compared to conventional drugs (Cordell,. 2000; Etkin, 2000; Balunas \& Kinghorn, 2005; Cordell \& Colvard, 2005; WHO, 2005). It is believed that combinatorial chemistry will be a the main source of synthetical medicine in the future (Simmonds \& Grayer, 1999).

In fact, however, combinatorial chemistry fails to provide a model for drug structure in several medical treatment (Simmonds, 2003; Butler, 2004), whereas the plants still provide more various structures than combinatorial chemistry (Muller, 2004). It is assumed that plants, as chemical factories, have continuously evolved their biosynthetic programs for more than 400,000 million years. As long as evolutionary process, these plants synthesize compounds in which the structural variety is far beyond the imagination of synthetical chemistry experts. It is really possible that the evolutionary pathway of secondary metabolite produces compounds enabling to cure diseases that cannot be healed by conventional medication. (Simmonds \& Grayer, 1999).

\section{Plants as a treatment for Male Sexual Problem}

Environment is one of crucial factors affecting human fertility. Contrast to infertility caused by genetical 
factors, infertility caused by environmental factor have possibility to cure and prevent (Quallich, 2006). One of the most important environment factors is nutrition (Ebisch et al., 2005). In this prespective, a traditional medicine using medicinal plant is very promising. Some research has shown a positive effect of nutrition in spermatogenesis. Recent studies show medicinal plant potency in improving male fertility and aphrodisiac on animal (Sinclair, 2000; MacKay, 2004).

The improvement of sexual function has been proven through the use of medicinal plants, like ginseng, yohimbe, tribulus terestis, and maca (Burkill, 1965; Waddell et.al., 1980; Lewis \& Elvin-Lewis, 2003). The traditional medication that is orally done by drinking the steeped water from the parts of the plant has been practiced over hundred years ago. In a medical treatment, the oral medication of sexual problem is a new thing. Viagra, the first pill to heal impotence, had just been launched in 1998. This medicine is a revolution in medical treatment, in which the previous medication was treated only by injection and operation. (Eardley, 1998; Mulhall, 2000; Elferink, 2000; Morales, 2001).

However, the development of the plant research is very slow. It happens because many researches conducted by pharmacy industries depend on the patent to get the profit. Plants cannot be patented therefore the industries are reluctant to invest their money to prove that certain plants are safe and effective (Foster \& Duke, 2000). There are no plants or botanical derivation compound that are legally certified by Food and Drug Association or other similar institutions to be used as a medication of sexual dysfunction (Sinclair, 2000; Nickell, 2001; MacKay, 2004).

\section{The difference between traditional medicine and modern medicine}

In the medical world in America and other developed countries, there is just a single chemical compound that is recognized as a medicine, not in the form of mixed chemical components existed in the plants. This recognition is preferably caused by the drug regulations and laws, not by the scientific consideration (Foster \& Duke, 2000) or philosophical belief that medicine works as 'one-target-one-disease' (Adimoelja, 2000; Wermuth, 2004). A dominant belief indirectly puts minor beliefs aside, consequently it reduces the supports towards scientific fields based on different philosophies (Kuhn, 1996).

Modern medicine relies on the view that a disease is caused by a very specific pathogen invaded to the body therefore the healing must be done by eradicating the source of the disease (Adimoelja, 2000). The medication using medicinal plants uses holistic approach by investigating the disease up to the main origin causing the unbalancing and deficiency in the body function (Cracker $\&$ Giblette, 2002). The whole body functions caused by the synergy and the existence of individual actions from body parts are the characteristics of living creatures therefore the reductionist view of the disease concept, that just blames an organ or a certain isolated mechanism, is an incomplete approach (Rangel, 2005).

\section{The Model of Medicinal Plant Study}

Nowadays, in vitro test for screening pharmaceutical agent is a main choice for many pharmacy companies but the success of the effort is limited on the beginning of the drug discovery program. This test has not yet fully replaced the use of animals in many toxicology studies and pharmacology experiments (White, 2001).

The understanding on molecular level cannot be automatically applicated to show that the medical strategy is effective. In vitro physiological reaction of a pharmaceutical can have an inaccurate prediction of in vivo physiological reaction. Many pharmaceutical agents show off different activities in various cell population. That ails in predicting the whole effect of giving an agent in the body (Walsh, 1998; Barton \& Andersen, 1998; Jobe et al., 1994). In vitro data is indirectly equivalent with in vivo data although in vitro test can provide the foundation to determine the study objective. The studies are continuously conducted to ensure how far in vitro data can replace in vivo data (Rodrigues, 1997).

The drug discovery program is basically based on the use of the experimental animals to determine the pharmacological effect and the compound/chemical metabolism (Briggs \& Oehme, 1980). An experimental model is important from a clinical point of view because there are many aspects of human physiological and biological reproduction that cannot be studied directly (Plant \& Marshall, 2001). A conventional test of medicinal plants using rodensia as an experimental animal model is really needed before pre-clinical and clinical tests can be conducted (Farnsworth, 1992). The result is often the only reference to determine the drug development from the pre-clinical test (Greaves, 1990). A rodent as an experimental animal has an important role in screening chemical agents to study the pharmacological effect covering the distribution, mechanism, and toxicity (Briggs \& Oehme, 1980). Evaluation of the effect of an agent towards a male reproduction system generally uses rodents as an animal model. The wide use of mouse species in the research has produced complete biology data. The research on fertility and male reproduction is conducted using various methods taken from toxicology, medical, ecology, and epidemiology (Golden, 2002).

\section{Bioassays for bioactive compound evaluation}

The combination of chemical and biological screening is the quickest method to get an active compound of the plant. To get this, the bioassays provision or simple pharmacological test is very important to focus on certain activities from the plants or various plant fraction as a guidance to obtain pure active component(s). This bioassays must be very sensitive because the active substance in the plants may be in a very low quantity. This 
bioassays must also be specific towards the desired target. The main target for Biology test can be divided into six groups, namely:

- Low organisms: microorganism

- Invertebrata: insects, crustacean, mollusca

- Isolated sub-celullar system: enzyme, receptor

- Animal and human cell culture

- Isolated organ

- Intact animal

Most bioassays are used in in vitro test in cells or subcells and the low animal test. In vivo test in complete animals is less conducted and less interested because of ethical issue and it is time-consuming (Hawcroft et al., 1987; Hamburger \& Hostettmann. 1991; Hostettmann \& Marston, 2002; Preusch, 2004).

Determining a simple and quick bioaassay to evaluate plant for improving sexual function is very difficult. Reproduction system is a very complicated system having existed complex interactions in the level of organs, cells and sub-cells. Moreover, there are many aspects of reproduction system that have not been studied and not certainly known (Kierzenbaum, 1994; de Kretser \& Baker, 1999; Liska, 2003; Huggins, 2003; Lopez-Gatius, 2006). Because of that, it is quite difficult to find simple and quick in vitro bioassays in those fields - those are not always provided. The only bioassay, that are reliable to test plants in improving sexual function, is in vivo test in intact animal although the test is time-consuming and expensive.

Bioassays offer an huge advantage in standardization and quality control of plant based product. The products are heterogen because there are a mixture of bio-active components from both a plant and mixture of several plants. The physical analysis method, like chromatography, cannot be used for this purpose because it is not sensitive towards the chemical complexity existed in plant crude extracts. It often happens that the desired biological activities are not evoked by single plant component but a mixture of various plant components therefore just relying on physical and chemical analyses towards a single component on a mixture is not really satisfying (Mclaughlin, 1998).

Unfortunately the objectives of many phytochemist is just isolate, characterize and publish various new compounds without testing their bio-activities. To attain practical uses, natural chemical substances must combine bioassays inside those substances. The extracts must be screened for biological activities, active extracts must be chosen, fraction must be directed to bioassays, bioactive compounds are finally identified and exploited (Mclaughlin, 1998).

\section{Experiment on Fertility and Male Sexual Function}

The researches conducted by Luthfi et al (2008) and Mat Noor \& Luthfi (2006) on tongkat ali (Eurycoma longifolia), sanrego (Lunasia amara), ginger (Alpinia galanga), dan clove (Syzygium aromaticum) show the potency of aphrodisiac and sanrego to improve man fertility. This study uses rat as tested animals. Rats are divided into two groups for different plant extracts, namely every group is given plant extracts in dose 3.33 $\mathrm{mg} / \mathrm{ml}$ and $333 \mathrm{mg} / \mathrm{ml}$ each and control group is given distilled water. Plant extracts or distilled water are given through force feeding once a day at 11.00 a.m. for 50 days. After having given plants extraxts for 50 days, the rat are sacrificed using chloroform and the epididymis were dissected out. Cauda epididymis were separated according to the Hamilton (1975). Sperm counts were determined using Improve Neubauer Hemocytometer as described previously (Prasad et al., 1972; NAFA \& ESHRE-SIGA, 2002) with some modification. In brief, cauda epididimis was minced in $15 \mathrm{ml} \mathrm{BWW}$ medium (Biggers et al., 1971) and incubated with $5 \% \mathrm{CO}_{2}$ for 30 minutes at $37^{\circ} \mathrm{C}$. Data were expressed as number of sperm per cauda epididymis. Progressive sperm motility was assesed subjectively based on WHO laboratory manual (1999). A study of sperm morphology is conducted by providing three slides of sperm smear for each rat. After fixated in methanol, the slide were stain with Giemsa. The dry slide is observed in a light microscope. One hundred sperms are counted randomly from every slide. The percentage of morphology of normal/abnormal sperms is determined referring to criteria stated by Wyobek and Bruce (1975).

Table 1 shows the number of each rat sperm which has been given aphrodisiac, sanrego, ginger and clove for 50 days. The average number of mouse sperms treated by aphrodisiac extracts at $333 \mathrm{mg} / \mathrm{ml}$ dosage $(46.23 \pm 1.77)$ and sanrego extracts at $333 \mathrm{mg} / \mathrm{ml}$ dosage $\left(47.30 \times 10^{6}+\right.$ 3.47) show that there is a significant improvement ( $p<$ 0.05 ) compared with the average number of sperms given ginger, clove extracts and control (distilled water). However, the intake of tongkat ali and sanrego extracts at $3.33 \mathrm{mg} / \mathrm{ml}$ dosage does not show any significant different in sperm number. A statistical analysis does not show any significant difference between groups treated with ginger extract, clove extracts, and control.

The morphology analysis result of rat sperm shows that the percentage of sperm with normal morphology in treated rat group and control group exceeds 95\%. A statistical analysis using Turkey test shows that there is no significant difference $(p>0.05)$ between control group and a treated group from the percentage of formal morphology sperm.

Table 1. Sperm number $\left(\mathrm{x} 10^{6}\right)$ and percentage of normal morphology sperm a of rat group given aphrodisiac, sanrego, ginger and clove extracts each at $3.33 \mathrm{mg} / \mathrm{ml}$ and $333 \mathrm{mg} / \mathrm{ml}$ dosage compared to control group.

\begin{tabular}{cccc}
\hline Treatment & Dosage & Sperm number $(\mathbf{x ~ 1 0})$ & \% Normal morphology sperm \\
\hline \multirow{2}{*}{ Tongkat ali } & $333 \mathrm{mg} / \mathrm{ml}$ & $46.23 \pm 1.77$ & $96.24 \pm 1.16$ \\
& $3.33 \mathrm{mg} / \mathrm{ml}$ & $34.16 \pm 3.37$ & $96.8 \pm 0.70$
\end{tabular}




$\begin{array}{llll}\text { Sanrego } & 333 \mathrm{mg} / \mathrm{ml} & 47.30 \pm 3.47 & 96.66 \pm 0.80 \\ & 3.33 \mathrm{mg} / \mathrm{ml} & 38.43 \pm 3.09 & 96.04 \pm 1.10 \\ \text { Ginger } & 333 \mathrm{mg} / \mathrm{ml} & 27.21 \pm 2.76 & 95.70 \pm 1.39 \\ & 3.33 \mathrm{mg} / \mathrm{ml} & 29.21 \pm 4.46 & 96.83 \pm 0.21 \\ \text { Clove } & 333 \mathrm{mg} / \mathrm{ml} & 31.67 \pm 1.91 & 96.48 \pm 1.35 \\ & 3.33 \mathrm{mg} / \mathrm{ml} & 32.43 \pm 2.76 & 96.71 \pm 0.47 \\ & & & \\ \text { Control } & & 33.17 \pm 4.25 & 96.67 \pm 0.63\end{array}$

The effect of aphrodisiac, sanrego, ginger and clove on sperm motility is shown in Table 2. A sperm motility analysis shows that tongkat ali and sanrego have the best effect in improving sperm movements compared with groups given clove, ginger extracts and control group (distilled water). The treatment of aphrodisiac and sanrego at high dosage $(333 \mathrm{mg} / \mathrm{ml})$ shows that $80 \%$ of sperm movements are in the a grade while control group shows only $40 \%$ of sperms movements are in the a grade. A group treated using ginger extracts at $333 \mathrm{mg} / \mathrm{ml}$ dosage on the contrary shows the lowest level of sperm motility, namely $80 \%$ in the level c. Sperm motility has been considered as one of the most important predictors of fertility. Several reports have demonstrated the correlation of motion parameters with fertilization rates (Liu et al., 1991). Further studies are required to confirm the mechanisms of action of tongkat ali and sanrego on sperm motility.

Table 2. Sperm motility grade in the treated group given aphrodisiac, sanrego, ginger and clove extracts each at $3.33 \mathrm{mg} / \mathrm{ml}$ and 333 $\mathrm{mg} / \mathrm{ml}$ dosage compared with a control group.

\begin{tabular}{|c|c|c|c|c|c|c|}
\hline \multirow{3}{*}{ Treatment } & \multirow{3}{*}{ Dosage } & \multicolumn{5}{|c|}{ Motility grade (a-d) } \\
\hline & & \multicolumn{5}{|c|}{ Individual rat } \\
\hline & & 1 & 2 & 3 & 4 & 5 \\
\hline \multirow[t]{2}{*}{ Tongkat ali } & $333 \mathrm{mg} / \mathrm{ml}$ & $\mathrm{a}$ & $\mathrm{a}$ & $\mathrm{b}$ & $\mathrm{a}$ & $\mathrm{a}$ \\
\hline & $33.3 \mathrm{mg} / \mathrm{ml}$ & $\mathrm{a}$ & $\mathrm{a}$ & $\mathrm{a}$ & $\mathrm{b}$ & $\mathrm{a}$ \\
\hline \multirow[t]{2}{*}{ Sanrego } & $333 \mathrm{mg} / \mathrm{ml}$ & $\mathrm{a}$ & $\mathrm{a}$ & $\mathrm{a}$ & $\mathrm{b}$ & $\mathrm{a}$ \\
\hline & $33.3 \mathrm{mg} / \mathrm{ml}$ & $\mathrm{a}$ & $\mathrm{a}$ & $\mathrm{b}$ & $\mathrm{b}$ & a \\
\hline \multirow[t]{2}{*}{ Ginger } & $333 \mathrm{mg} / \mathrm{ml}$ & $\mathrm{c}$ & $\mathrm{c}$ & $\mathrm{c}$ & $\mathrm{b}$ & $\mathrm{c}$ \\
\hline & $33.3 \mathrm{mg} / \mathrm{ml}$ & $\mathrm{b}$ & $\mathrm{c}$ & $\mathrm{c}$ & $\mathrm{b}$ & $\mathrm{b}$ \\
\hline \multirow[t]{2}{*}{ Clove } & $333 \mathrm{mg} / \mathrm{ml}$ & $\mathrm{b}$ & $\mathrm{b}$ & $\mathrm{b}$ & $\mathrm{b}$ & $\mathrm{b}$ \\
\hline & $33.3 \mathrm{mg} / \mathrm{ml}$ & $\mathrm{b}$ & $\mathrm{b}$ & $\mathrm{b}$ & $\mathrm{b}$ & c \\
\hline Control & Distilled Water & $\mathrm{b}$ & $\mathrm{a}$ & $\mathrm{b}$ & $\mathrm{b}$ & $\mathrm{a}$ \\
\hline
\end{tabular}

Note for the grade of motility WHO (1999)

(a): rapid progressive motility ; $\geq 25 \mu \mathrm{m} / \mathrm{s}$, (b): slow or sluggish progressive motility, (c): non progressive motility ; $<5 \mu \mathrm{m} / \mathrm{s}$, (d): immotile.

This study shows that cloves and gingers do not improve the parameter of male fertility, namely the numbers of sperms, the movements of sperms, and the normal morphology of sperms.

Both plants on the contrary decrease the number of sperms although it is not significant $(\mathrm{P}>0.05)$. The report written by Jaganath and $\mathrm{Ng}(2000)$ shows that gingers can improve sperm number and sperm motility is incompatible with the result of this study. This result is difficult to compare because there are differences of tested animals and there may be differences in providing extracts that are not explicitly stated in detail in the report.

A study conducted by Luthfi and Mat Noor (2007) also shows that sanrego increase sexual behavior of male rat. Table 3 shows the aphrodisiac effect in male rat after they are given sanrego at a certain dosage (the treatment group) and distilled water (a control group). The 60 $\mathrm{mg} / \mathrm{kg}$ dosage shows that the number of mounting is increase significantly compared with other groups. The numbers of mounting in the group using 60 and $90 \mathrm{mg} / \mathrm{kg}$ dosages do not show any significant differences. The decrease of mounting number at $90 \mathrm{mg} / \mathrm{kg}$ dosage is difficult to explain with the data from the result of the study. It may be caused by the limited number of tested rat (sample). Hayes (2001) stated that the more number of mice, the more consistent the result. The research is still conducted to isolate active compounds from sanrego that can improve aphrodisiac or male fertility.

Table 3. The average mounting number of male rat after treating sanrego extract using various dosages.

\begin{tabular}{lc}
\hline Treatment Dosage & $\begin{array}{c}\text { The average of mounting } \\
\text { number }+ \text { SE }\end{array}$ \\
\hline Kontrol & $1.33+1.54$ \\
$30 \mathrm{mg} / \mathrm{kg}$ & $2.33+0.57$ \\
$60 \mathrm{mg} / \mathrm{kg}$ & $3.33+0.57$ \\
$90 \mathrm{mg} / \mathrm{kg}$ & $3.00+0.00$ \\
\hline
\end{tabular}

The early research on purwoceng (Pimpinella pruatjan) also shows its potency as aphrodisiac herb (Tambunan, 2005). The root of purwoceng can be used as aphrodisiac, diuretic and tonic herbs. At this moment, the information about bioactive content in purwoceng has not been known yet. Some bioactive compounds that have been identified are stigmaterol and sitosterol but no one has reported the use of the single compounds. 


\section{The Direction of the Medicinal Plant Development in the Future}

Most research synthetic organic and natural compounds are conducted by pharmaceutical company and industries. The research is focused to look for new and more powerful compounds. In the university, a study must not always be directed to find new compounds but the study can also look for substances showing certain biological activities that may help in understanding on physiological effects.

The study of medicinal plants to treat sexual dysfunction is ideally conducted using an experimental approach that is wellknown reliable to find bioactive compounds, that is bioassay-guided isolation. Plants are chosen based on ethnopharmacology criteria, then the plants are extracted. Extracts produced are tested using relevant bioassays system. After biological activities are determined, active extracts are fractionated and their biological activities are monitored for each level of fraction. Active isolat elucidation is finally conducted.

There are several possibility if extraxts and fractions show bioactivity but each compound is not active. The first possible reason is that there is a synergy effect in those compounds. Bioactivity emerges because there is a synergy among those compounds (Williamson, 2001) but there is another possible reason that there are some components that have not been isolated. It occurs because a single plant extract can contain hundreds components from various different groups, either primary and secondary metabolit. Those group are isoprenoid, fenol, lipid, cabohydrate and its derivations, amino acid and mineral. All those subtances have possibilities to be bioactive (Wildman, 2001). In this case, in a research of plant having a potency to improve fertility, it has a slight possibility to get active components because in vivo testing needs more numbers of components to test.

In that case, a pharmacological testing to test extracts that produces standardized extraxts can be conducted. After a study of toxicity and safety of the extract are conducted, the standardized extracts are formulated. Then, a product can be developed. This product can be a first step for an innovative local pharmaceutical industry and it can compete with western pharmaceutical industries, not only for common diseases but also for severe diseases (Pieters and Vlietinck, 2005).

\section{Conclusion}

A number of medicinal plants show the promising potency in treating male sexual problems. Medicinal plants have their own characteristics that cannot fully fulfilled the research methods of conventional medicines. The results of the research show that some practices using medicinal plants can validly healing male sexual dysfunction and it can be improved in order to have a cheap effective safe therapy of the disease. It is hoped that the wide spread of the botanical medicine interest and knowledge will reduce obstacles in using and developing the medicinal plants.

\section{References}

Adimoelja, A. 2000. Phytochemicals and the Breakthrough of Traditional Herbs in the Management of Sexual Dysfunctions. Int. J. Androl. 23, suppl.2: 82-84

Aminudin, N. 2004. Eurycoma Longifolia Jack Aqueous Extract: Bioactive Compound and its Effects toward Hormone Production and Spermatogenesis. Doctorate Thesis. Institute of Biology Science, Faculty of Science. University of Malaya. Kuala Lumpur. Unpublished.

Balandrin, M. F., J. A. Klocke, E. S. Wurtele, and W. H. Bollinger. 1985. Natural Plant Chemicals: Sources of Industrial and Medicinal Materials. Science 228: 1154-60.

Balunas, M.J., A.D. Kinghorn. 2005. Drug Discovery from Medicinal Plants. Life Sciences 78: 431-441

Barton, H.A., M.E. Andersen. 1998. A Model for Pharmacokinetics and Physiological Feedback among Hormones of the Testicular-Pituitary Axis in Adult Male Rats: A Framework for Evaluating Effects of Endocrine Active Compounds. Toxicological Sciences 45: 174-187

Bindseil, K. U., J. Jakupovic, D. Wolf, J. Lavayre, J. Leboul, D. van der Pyl. 2001. Pure Compound Libraries; A New Perspective for Natural Product based on Drug Discovery. DDT 6 (16): 840-847

Briggs, S. 2004. The Emerging Field of Systems Biology and Its Potential Role in Understanding Disease. BioSphere Winter 5: 7

Briggs, G.B., F. W. Oehme. 1980. Toxicology. In The Laboratory Rat. Volume II. Researh Application (eds. H.J. Baker et al.). Academic Press. New York. P: 104-118

Burkill, J.H. 1966. A Dictionary of Economic Products of the Malay Peninsula. Art Printing Works, Kuala Lumpur. 2 vols.

Colvard M.D., G. A. Cordell, R.Villalobos, G. Sancho, D.D. Soejarto, W. Pestle, T. L. Echeveri, K. M. Perkowitz, J. Michel. 2006. Survey of Medical Ethnobotanicals for Dental and Oral Medicine Conditions and Pathologies. Journal of Ethnopharmacology 107: 134-142

Cordell, G.A. 2000. Biodiversity and Drug Discovery-a Symbiotic Relationship. Phytochemistry 55: 463-480

Cordell, G.A., M.A. Colvard. 2005. Some Thoughts on the Future of Ethnopharmacology. Journal of Ethnopharmacology 100: 514

Clouatre, D. 2005. New Help Male Fertility. Total Health 26/4: 2627

Craker, L. E., J. Giblette. 2002. Chinese Medicinal Herbs: Opportunities for Domestic Production. In Trends in New Crops and New Uses (eds. J. Janick and A. Whipkey). ASHS Press, USA. pp: 491-496

De Kretser, D. M., H. W. G. Baker. 1999. Infertility in Men: Recent Advances and Continuing Controversies. The Journal of Clinical Endocrinology \& Metabolism 84 (10): 3443-3450

Ebisch, I.M.W., F.H. P. Pierik, F.H. De Jong, C.M.G. Thomas, R.P.M. Steegers-Theunissen. 2006. Does Folic Acid and Zinc Sulphate Intervention Affect Endocrine Parameters and Sperm Characteristics in Man? Int. J. Andr. 29(2): 339-345

Eardley, I. 1998. New Oral Therapies for the Treatment of Erectile Dysfunction. British Journal of Urology 81: 122-127

Elferink, J.G.R. 2000. Aphrodisiac Use in Pre-Columbian Aztec and Inca Culture. Journal of the History of Sexuality 9 (1): 25 36.

Etkin, N.L. 2001. Perspectives in Ethnopharmacology: Forging a Closer Link between Bioscience and Traditional Empirical Knowledge. Journal of Ethnopharmacology 76: 177-182 
Farnsworth, N.R. The Role of Ethnopharmacology in Drug Development. In Bioactive Compounds from Plants. John Wiley \& Sons 1990. Chichester.2-11

Farnsworth, N.R. 1992. Preclinical Assesment of Medicinal Plants. In Natural Resources and Human Health - Plants of Medicinal and Nutritional Value. Eds. S. Baba, O. Akerele, Y. Kawaguchi. Elsevier. Amsterdam. p: 89

Foster, S., J.A. Duke. 2000. A Field Guide to Medicinal Plants and Herbs. Second Edition. Houghton Mifflin Company. Boston.

Gilani, A. H., Atta-ur-Rahman. 2005. Trends in Ethnopharmacology. Journal of Ethnopharmacology 100: 4349

Golden, A.L. 2002. Biomarkers of Male Reproductive Health. In Biomarkers of Environmentally Associated Diseas. Technologies, Concepts, and Perspectives (eds. S.H. Wilson and W.A. Suk). Lewis Publisher. New York. P: 387-410

Goldman, P. 2001. Herbal Medicines Today and the Roots of Modern Pharmacology. Ann Intern Med. 135:594-600

Hamadeh, M. E., T. Zeginiadov, P. Rosenbaum. 2001. Predictive Value of Sperm Chromatin Condensation (Aniline Blue Staining) in the Assessment of Male Fertility. Archives of Andrology 46: 99-104

Hamburger, M., K. Hostettmann. 1991. Bioactivity in Plants: the Link between Phytochemistry and Medicine. Phytochemistry 30 (12): 3864-3874

Hawcroft, D., T. Hector, R. Rowell. 1987. Quantitative Bioasay. John Wiley and Sons. London. P 1-20.

Hayes, A.W. 2001. Principles and Methods of Toxicology. Fourth Edition. Taylor and Francis. USA. p: 1269

Hostettmann, K., A. Marston. 2002. Twenty Years of Research into Medicinal Plants: Results and Perspectives. Phytochemistry Reviews 1: 275-285

Huggins. 2003. Alternatives to Developmental/Reproductive Toxicity Testing in Animals. ALTEX 20, Suppl.1: 32-41

Jaganath, I.B. and Ng, L.T. 2000. HERBS The Green Pharmacy of Malaysia. Malaysia Agricultural Research and Development Institute (MARDI)

Jobe, P.J., L.E. Adam-Curtis, T.F. Burks, R. W. Fuller, C.C. Peck, R.R. Ruffolo, O. C. Snead III, R.L. Woosley. 1994. The Essential Role of Integrative Biomedical Sciences Protecting and Contributing to the Health and Well-Being of Our Nation. The Physiologist 37 (3): 79-86

Lewis, W.H., M.P.F. Elvin-Lewis. 2003. Medical Botany Plants Affecting Human Health. Second Edition. John Wiley and Sons. New Jersey. p : 586-592

Liu, D. Y., Clarke, G. N., \& Baker, H. W. G. (1991). Relationship between sperm motility assessed with the Hamilton-Thorn motility analyzer and fertilization rates in vitro. Journal of Andrology, 12, 231-239.

Kierzenbaum, A. 1994. Mammalian Spermatogenesis in Vivo and in Vitro: A Partnership of Spermatogenic and Somatic Cell Lineages. Endocrine Reviews 15 (1): 116-134.

Kohn, F.M. 2001. Nonmedical and Naturopathic Approaches to Treatment of Male Fertility. In Proceedings of the 7th Andrology Symposium. Treatment of Male Infertility Viewpoints, Controversies, Perspectives. Giessen, Germany. p: 337

Kuhn, T. S. 1996. The Structure of Scientific Revolution. Third Edition. University Of Chicago Press. Chicago.

LaFrance Jr, W.C., E. C. Lauterbach, C. E. Coffey, S. P. Salloway, D. I. Kaufer, A. Reeve, D. R. Royall, E. Aylward, T. A. Rummans, M. R. Lovell. 2000. The Use of Herbal Alternative Medicines in Neuropsychiatry. $J$ Neuropsychiatry Clin Neurosci 12: 177-192

Lefie'vre L., K. Bedu-Addo, S. J. Conner, G. S. M. MachadoOliveira, Y. Chen, J.C.Kirkman-Brown, M. A. Afnan, S. J. Publicover, W.C. L. Ford, and C. L. R. Barratt. 2007. Counting Sperm does not Add Up Any More: Time for A New Equation? Reproduction 133: 675-684
Liska, F., 2003. Selected Genetic Aspects of Male Infertility - What Animal Models Tell Us. Folia Biologica 49:129-141

Lopez-Gatius, F., I. Garcia-Ispierto, P. Santolaria, J. Yaniz , C. Nogareda, M. Lopez-Bejar. 2006. Screening for High Fertility in High-Producing Dairy Cows. Theriogenology 65:16781689

Luthfi, M. J., M. Mat Noor. 2008. Kesan Akstrak Akuas Lunasia Amara Blanco terhadap Kualiti Sperma dan Kelakuan Seksual Tikus Jantan. Prosiding Kolokium Siswazah ke-7. Universiti Kebangsaan Malaysia. Bangi.

Luthfi, M. J., M. Mat Noor, J. Latip. 2008. Penskrinan Beberapa Tumbuhan yang Berpotensi meningkatkan kualitas sperma tikus. Prosiding Konferensi Ilmiah ke-3 Persatuan Pelajar Indonesia. Universiti Kebangsaan Malaysia. Bangi.

MacKay, D. 2004. Nutrients and Botanicals for Erectile Dysfunction: Examining the Evidence. Alter. Med. Rev. 9 (1): 4-16

Mendonça-Filho, R.R. 2006. Bioactive Phytocompounds: New Approaches in the Phytosciences. In Modern Phytomedicine. Turning Medicinal Plants into Drugs (eds. I. Ahmad, F. Aqil, and M. Owais). Wiley-VCH Verlag GmbH \& Co.Weinheim. $\mathrm{p}: 1-24$

Meyerson, B. J., L. Lindstrom, E. B. Nordstrom, A. Agmo. 1973 Physiology Behaviour, 11: 421-428.

McLaughlin, J.L., L.L. Rogers, J.E. Anderson. 1998. The Use of Biological Assays to Evaluate Botanicals. Drug Information Journal 32: 513-524

Millen, J. 1962. The Nutritional Basis of Reproduction. London: Charles C. Thomas Publisher

Mat Noor, M., M. J. Luthfi. 2006. Penabiran Lima Herba yang Berpotensi dalam Meningkatkan Parameter Kesuburan Haiwan Jantan. Prosiding Seminar Bersama UKM-UNRI. Pusat Kembangan Pendidikan. Universiti Kebangsaan Malaysia. Bangi.

Mat Noor, M., A.H.S. Mohd Nor, L.C. Hassan. 2004. The Effect of Eurycoma Longifolia Jack (Tongkat Ali) on Sexual Behaviour and Sperm Quality in Rats. Malaysian Journal of Pharmaceutical Sciences 2 (1): 53-60

Morales, A. 2001. Yohimbine in Erectile Dysfunction:Would an Orphan Drug ever be properly Assessed? World J. Urol. 19: 251-255

Müller, W.E.G., H.C. Schröder, M. Wiens, S. Perovic'-Ottstadt, R. Bate, I.M. Müller. 2004. Traditional and Modern Biomedical Prospecting: Part II-the Benefits. Evidenced-based Complementary and Alternative Medicine

Mulhall, J.P. 2000. Clinical Perspective on Erectile Dysfunction Therapies. The American Journal of Managed Care Vol 6 No 12: S641-S643

Newton P (1991) The Use of Medicinal Plants by Primates: A Missing Link? Trends Ecol Evol 6: 297-299

Nickel, L.N. 2001. Nature's Aphrodisiacs. Crossing Press. USA.

Orgebin-Crist, M. 1998. The Epididymis across 24 Century in The Epididymis Cellular and Molecular Aspects (eds. Russell C. Jones et al.). Journal of Reproduction and Fertility Supplement $53,285-292$

Pei, J., E. Strehler, U. Noss, M. Abt, P. Piomboni, B. Baccetti, K. Sterzik. 2005. Quantitative Evaluation of Spermatozoa Ultrastructure after Acupuncture Treatment for Idiopathic Male Infertility. Fertility and Sterility 84(1) : 141-147

Pieters, L., A. J. Vlietinck. 2005. Bioguided Isolation of Pharmacologically Active Plant Components, still A Valuable Strategy for the Finding of New Lead Compounds? Journal of Ethnopharmacology 100: 57-60

Plant, T.M., and G.R. Marshall. 2001. The Functional Significance of FSH in Spermatogenesis and the Control of Its Secretion in Male Primates. Endocrine Reviews 22(6):764-786

Prasad, M. R. N., N.J. Chinoy, K.M. Kadam. 1972. Changes in Succinic Dehydrogenase Levels in the Rat Epididymis under Normal and Altered Physiologic Conditions. Fertility and Sterility 23 (3): 186-190. 
Preusch, P.C. 2004. Integrative and Organ Systems Pharmacology: A New Initiative from the National Institute of General Medical Sciences. Molecular Intervention 4 (2): 72-73

Quallich S., 2006. Examining Male Infertility. Urologic Nursing 26 (4): 277-288.

Rangel, J.A.O. 2005. The Systemic Theory of Living Systems and Relevance to CAM: the Theory (Part III). Evidenced-based Complementary and Alternative Medicine 2 (3): 267-267

Rodrigues, A.D. 1997. Preclinical Drug Metabolism in the Age of High-Throughput Screening: An Industrial Perspective. Pharmaceutical Research 14 (11): 1504-1510.

Simmonds, M.S.J. 2003. Novel Drugs from Botanical Sources. DDT 8 (16): 721-722

Sinclair, S. 2000. Male Infertility: Nutritional and Environmental Considerations. Alternative Medicine Review 5 (1): 28-38

Tambunan, I.K. 2005. Prospek Penelitian dan Pengembangan Purwoceng. Warta Biogen 1 (1): 10-11

Waddell, T.G., H. Jones, A. L. Keith. 1980. Legendary chemical aphrodisiacs. Journal of Chemical Education 57(5): 341-342.
Walsh, G. 1998. Biopharmaceutical: Biochemistry and Biotechnology. John Wiley \& Sons. Chichester. p: 37-39.

Wermuth, C.G. 2004. Multi-targeted Drugs: The End of the 'OneTarget-One-Disease' Philosophy? Drug Discovery Today 9: 826-827

Williamson, E.M. 2001. Synergy and other interaction in phytomedicines. Phytomedicine 8 (5): 401-409.

White, W.J. 2001. The Use of Laboratory Animals in Toxicologic Research. In Principles and Methods of Toxicology. Fourth Edition (ed. A.W. Hayes). Taylor and Francis. Philadelphia. P: 773-775

WHO. 1999. Laboratory Manual for the Examination of Human Semen and Semen-Cervical Mucus Interaction. New York: Cambridge University Press.

WHO, 2005. National Policy on Regulation of Herbal Medicines. WHO Drug Information vol 19 no. 3: 216

Wyrobek, A.J., W.R. Bruce. 1975. Chemical Induction of Sperm Abnormalities in Mice. Proc. Natl. Acad. Sci. USA 72: 4426 
